production of new varieties or species is the isolation of a portion of the race, appears very luminous. On this subject, let me again quote from Darwin :-

"Youatt gives an excellent illustration of the effects of a course of selection, which may be considered as unconsciously followed, in so far that the breeders could never have expected, nor even have wished, to produce the result which ensuednamely, the produc ion of two distinct strains. The two flocks of Leicester sheep kept by Mr. Buckley and Mr. Burgess, as Mr. Youatt remarks, "have been purely bred from the original stock of Mr. Bakewell for upwards of fifty years. There is not a suspicion existing in the mind of anyone at all acquainted with the subject that the owner of either of them has deviated in any one instance from the pure blood of Mr. Bakewell's flock, and yet the difference between the sheep possessed by these two gentlemen is so great that they have the appearance of being quite different varieties" " "Origin of Species," $4^{\text {th }}$ edition, $P F \cdot 37,38$ :

Belfast, April 24.

THE fifth caudal vertebra of a tortoiseshell cat at the Sussex County Hospital is dislocated and attached at right angles to the long axis of the fourth. The sixth and last vertebra is also affixed at right angles to the fifth. The cat is able to wag the terminal phalanx of the tail, and the distortion has always been considered to be due to an accident when the animal was a kitten. Within the last week the cat has had a litter of several kittens, two of which were born almost tailless, one possessing (as far as I could ascertain by external manipulation) two caudal and the other three caudal vertebræ only. Whether the original distortion is due to accident or not, I think these facts may interest some readers of NATURE.

Brighton, A pril 28.

P.S. - Since writing the above note I have had an opportunity of examining the two remaining kittens of the litter, and I find that only one of these has a normal tail. The other is docked of one or two of the terminal vertebræ, and the tail has a slight twist on itself towards the end.

April 30.

\section{Variation in the Nesting-habits of Birds.}

IN considering the interesting question of instinct, one naturally turns to the nesting-habits of birds as affording an apparently good instance of habit acquired and perpetuated so as to become fixed, and, as we say, instinctive. It would be in teresting, however, to find exactly how far the art of nestbuilding is really inherited, and how much uniformity exists among the nests of birds of identical specific characters.

The "blackbird" of this region, Scolecophagus cyanocethalus, is rather noteworthy in this connection. Goss, in his "Birds of Kansas," says this bird breeds in trees and bushes, from three to thirty feet from the ground. In Colorado, as observed by $\mathrm{Mr}$. Morrison and myself, it breeds sometimes on the ground, and sometimes in low trees or bushes. In Custer County, Colorado, I find it breeding on the ground, sometimes at the very edge of creeks, in places where arboreal nests might have been made, and also better concealed ones. Captain C. E. Bendire, who inclines to the opinion that this bird breeds diversely in all parts of its range, where opportunities offer, writes (in litt.):- " "I have found them nesting ahundantly both on the ground and in bushes in the same locality and close together in Oregon. One thing struck me as peculiar : the nests when placed on the ground were almost always to be found on the extreme edge of a creek bank, when they could have selected far more suitable places, better concealed ones at any rate, a few feet away from the bank." This selection of creek banks, noticed both in Colorado and in Oregon, is remarkable. It had occurred to me that in Colorado the habit might have been formed to lessen the risk of being trampled upon by the herds of buffalo which used to inhabit this region, but Captain Bendire tells me the habit is observed also in regions where there never were any buffalo, which throws doubt upon my explanation.

Captain Bendire, who has so excellent a knowledge of the nesting-habits of American birds, kindly gives me a few notes on the subject, which it may be permissible to quote.

"Birds in the selection of their nesting-sites will adapt themselves to circumstances, as is well known, but as in the case just mentioned [Scolecophagus] it is hard to arrive at an entirely satisfactory conclusion. It is, for instance, easy to account for, why the Archibuteo ferrugineus should breed on the ground in Dakota, in many cases at any rate, and why Falco peregrinus anatum in trees in Kansas, but there are a number of other such departures from the old established rules, which cannot be so easily accounted for" (C. E. Bendire, in litt., January 2 I, I890). Captain Bendire also cites Buteo swainsoni and Archibuteo ferrugineus as birds which sometimes nest on the ground in places where there is plenty of suitable timber, which one might have expected them to make use of.

These variations in habit are certainly puzzling : probably the important factors in deciding the terrestrial or arboreal nestinghabits of a bird are four :-

(I) Ability to build arboreal nests. - If this varied in a locality where arboreal nests were not greatly preferable to terrestrial ones, we can see how a minority of clever birds might build in trees, and a majority of duffers on the ground. The slight disadvantage to the ground-builders might be counterbalanced by their numbers.

(2) Danger of falling.--In regions where the trees are not suitable for holding nests, or where very high winds prevail, a terrestrial nest might be preferable; though the same species in another part of its range might do well to build arboreally.

(3) Dangers of nesting on the ground. - Such dangers would arise from terrestrial enemies, floods, \&c., and would vary greatly no doubt in different regions. Where things were otherwise fairly balanced, a slight difference in this respect might decide the nesting of a bird.

(4) Means of defence.-Some birds, with special means of defence or of escaping observation, might build on the ground where others would take to trees.

West Cliff, Custer Co., Colorado.

\section{Russian Transliteration.}

I AM afraid the authors of the "new system" of transliteration have misunderstood my letter in yours of April ro (p. 534), advocating "the tabulation of the system of transliteration which has been so long in use in this country" in preference to the adop. tion of the unnecessary novelties they propose to introduce. By the "system in use" I meant that for transliteration from Russian into English, and certainly did not include the transliterations from Russian into German which have been copied from books or memoirs in that language into English catalogues or journals. As practically all the examples the authors adduce in defence of their "new system," including both the atlases and the works with which they associate my name, are of this kind-i.e. merely copies of transliterations from Russian into German-I fail to see what bearing they have on the question of transliteration into English, however useful they might be in constructing a system for transliteration from Russian into German.

Another misapprehension is, they seem to imagine that $\mathrm{I}$ have propounded a system of transliteration of my own. I sincerely hope I shall never be guilty of doing anything so rash. I merely offered some friendly criticisms on the new system which the authors had devised, and I may supplement my remarks by here giving in tabular form the principal points in which this system differs from that which $I$ conceive to be the English use :-

\begin{tabular}{|c|c|c|c|c|}
\hline & & English Use. & & New System. \\
\hline B & $\cdots$ & $v$ & $\cdots$ & \\
\hline B̈ & $\ldots$ & $f f$ & $\cdots$ & $v$ \\
\hline r & ... & $\begin{array}{l}h \text { before } e \text { or } i \text {, } \\
\text { otherwise } g\end{array}$ & $\ldots$ & $g / 2$ \\
\hline ж & $\cdots$ & $j$ & $\cdots$ & $2 h$ \\
\hline $\mathrm{kC}$ & $\ldots$ & $x$ & $\ldots$ & $k s$ \\
\hline y & $\ldots$ & $o u$ & $\cdots$ & $u$ \\
\hline $\mathrm{x}$ & $\ldots$ & $c h$ & $\ldots$ & $k h$ \\
\hline$\Psi$ & $\ldots$ & tch & $\ldots$ & $c h$ \\
\hline щ & $\ldots$ & shtch & $\ldots$ & shch \\
\hline 为 & $\ldots$ & $e$ & $\ldots$ & yo \\
\hline iĭ & $\ldots$ & $y$ & $\ldots$ & $i z$ \\
\hline 10 & $\ldots$ & $u$ & $\ldots$ & $y u$ \\
\hline
\end{tabular}

I have already given a few examples of names which look uncouth when transliterated according to the new system, and I here add one more. It is

\section{SKRZHIPSKIĬ.}

When I wrote it down and observed its hieroglyphic appearance, there arose somehow in my mind a vision of a new system of chemical nomenclature devised many years ago by Laurent, 